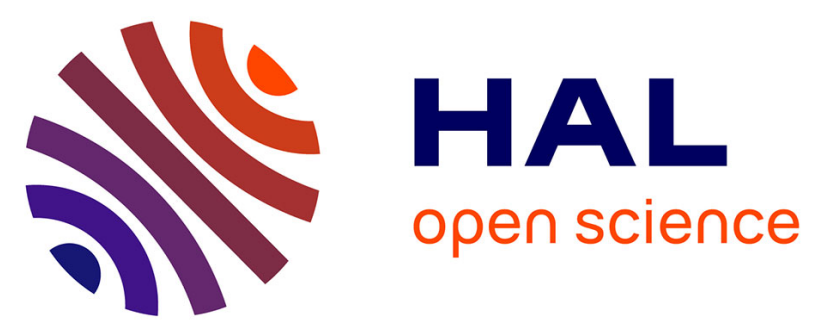

\title{
DETERMINATION OF DEFECT MOLECULAR UNITS IN K2SnCl6 AND AMMONIUM HALIDES VIA DIPOLAR RELAXATION AT PHASE TRANSITIONS
}

J. Winter, K. Rössler

\section{To cite this version:}

J. Winter, K. Rössler. DETERMINATION OF DEFECT MOLECULAR UNITS IN K2SnCl6 AND AMMONIUM HALIDES VIA DIPOLAR RELAXATION AT PHASE TRANSITIONS. Journal de Physique Colloques, 1976, 37 (C7), pp.C7-265-C7-270. 10.1051/jphyscol:1976763 . jpa-00216923

\section{HAL Id: jpa-00216923 https://hal.science/jpa-00216923}

Submitted on 1 Jan 1976

HAL is a multi-disciplinary open access archive for the deposit and dissemination of scientific research documents, whether they are published or not. The documents may come from teaching and research institutions in France or abroad, or from public or private research centers.
L'archive ouverte pluridisciplinaire HAL, est destinée au dépôt et à la diffusion de documents scientifiques de niveau recherche, publiés ou non, émanant des établissements d'enseignement et de recherche français ou étrangers, des laboratoires publics ou privés. 


\title{
DETERMINATION OF DEFECT MOLECULAR UNITS IN $\mathbf{K}_{2} \mathrm{SnCl}_{6}$ AND AMMONIUM HALIDES VIA DIPOLAR RELAXATION AT PHASE TRANSITIONS
}

\author{
J. WINTER and K. RÖSSLER \\ Institut für Chemie der Kernforschungsanlage Jülich GmbH, Institut 1 : \\ Nuklearchemie, D-5170 Jülich, FRG
}

\begin{abstract}
Résumé. - Les défauts des unités moléculaires dans des isolants peuvent être déterminés par des mesures de conductivité électrique et de thermocurent ionique (ITC). Les conditions sont un moment dipolaire électrique permanent du défaut et la présence de transitions de phase, qui augmentent la probabilité de relaxation dipolaire et, par conséquent, la sensibilité de la détection. Les méthodes sont appliquées à $\mathrm{K}_{2} \mathrm{SnCl}_{6}, \mathrm{NH}_{4} \mathrm{Cl}$ et $\mathrm{NH}_{4} \mathrm{Br}$, composants qui possèdent des unités anioniques octahédrales ou cationiques tétrahédrales en rotation quasi libre. La dissociation thermique ou l'irradiation par des neutrons créent les défauts dipolaires stables : $\mathrm{SnCl}_{5} \square^{-}$et $\mathrm{NH}_{3}$. La réorientation de ces unités lors de transitions de phase provoque des maximums très raides de courant de dépolarisation. Des concentrations de défauts de l'ordre de la partie par nanomol (ppb) peuvent être déterminées.
\end{abstract}

Abstract. - Defect molecular units in insulators can be determined by D. C. conductivity and ITC measurements. Conditions are a permanent electric dipole moment of the defect and the occurrence of phase transitions increasing the probability of dipolar relaxation and, thus, the sensitivity of detection. The methods are applied to $\mathrm{K}_{2} \mathrm{SnCl}_{6}, \mathrm{NH}_{4} \mathrm{Cl}$ and $\mathrm{NH}_{4} \mathrm{Br}$, compounds with quasi-free rotating octahedral anionic and tetrahedral cationic units, respectively. Thermal dissociation or neutron irradiation create stable dipolar defects $\mathrm{SnCl}_{5} \square^{-}$or $\mathrm{NH}_{3}$. The reorientation of these units at phase transitions causes sharp depolarization peaks. Defect concentrations at ppblevel can be measured.

Introduction. - Molecular units in ionic crystals very often can perform rotational movements. A change in this particular degree of freedom occurs most drastically at phase transformations. The onset of rotation can be used to determine defects of the covalent units, provided they respond to external fields, e. g. by a permanent dipole moment. The sensitivity of detection can be very high, since the defect species may be forced to rotate cooperatively at the transition point. A coupling of the movement of damaged and undamaged units assumed, defects may serve as a probe for phase transitions and lattice dynamics.

Very simple systems of ionic crystals with molecular units are the hexahalometallates of the type $\mathrm{R}_{2} \mathrm{MX}_{6}$, the high temperature phase of which in general is cubic of the antifluorite-type $\left(\mathrm{O}_{\mathrm{h}}^{5}-\mathrm{Fm} 3 \mathrm{~m}\right)$. The primitive cell in figure 1 , upper part, shows cubes of cations alternatively empty and occupied by an anion. $\mathrm{K}_{2} \mathrm{SnCl}_{6}$ [1] lends itself for the study of defects of the octahedral anions, since a mild irradiation with thermal neutrons creates almost exclusively $\mathrm{SnCl}_{5} \square^{-}$ligand vacancies and interstitial chlorine atoms via $(\mathrm{n}, \gamma)$-recoil processes. From hot atom chemistry experiments [2-5] it has already been concluded that the structure of the $\mathrm{MX}_{5} \square^{-}$-unit is a square pyramide.
This ligand arrangement is also implied by the existence of stable pentacoordinated compounds with similar structure such as $\left(\mathrm{NH}_{4}\right)_{2}\left[\mathrm{SbCl}_{5}\right]$ [6]. Due to the asymmetric charge distribution, $\mathrm{SnCl}_{5} \square^{-}$has a permanent dipole moment the orientation of which is randomly distributed between the equivalent positions within the cation cube, cf. figure 1 , lower part.

Most of the hexahalometallates undergo phase transitions at lower temperatures [7]. Some of them have been suggested to be due to the condensation of an optical phonon involving the rotation of the octahedra [8]. $\quad \mathrm{K}_{2} \mathrm{SnCl}_{6}$ exhibits two phase transitions at $T_{1}=262 \mathrm{~K}$ and $T_{2}=253 \mathrm{~K}[7,9-15]$. The occurrence of rotational movements renders $\mathrm{D}$. $C$. conductivity and ITC methods [16] to be a promising tool for the determination of dipolar anionic defects.

In this respect, $\mathrm{NH}_{4} \mathrm{Cl}$ and $\mathrm{NH}_{4} \mathrm{Br}$ form a system analogous to the hexahalometallates. Changes in the orientation of the $\mathrm{NH}_{4}^{+}$-ions occur at the well-known transitions at $T_{2}=243 \mathrm{~K}$ and $235 \mathrm{~K}$, respectively [17-22]. These rotations seem to be promising aides for the detection of ligand vacancies in $\mathrm{NH}_{4}^{+}$, i. e. dipolar $\mathrm{NH}_{3}$-units. The electric conductivity of the ammonium halides is partially due to proton transfer [23-28] which leads to the formation of dipolar $\mathrm{NH}_{3}$-species. A certain amount of $\mathrm{NH}_{3}$ is substitu- 


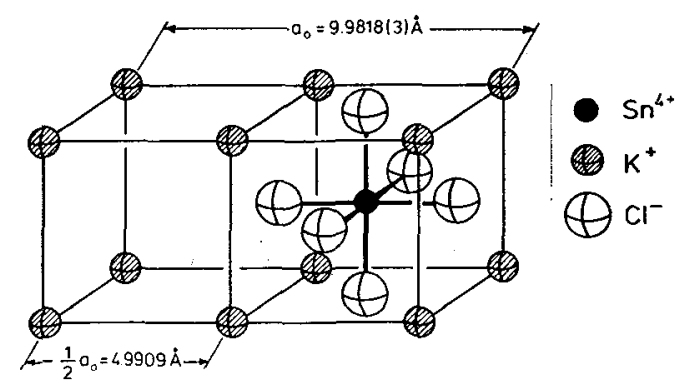

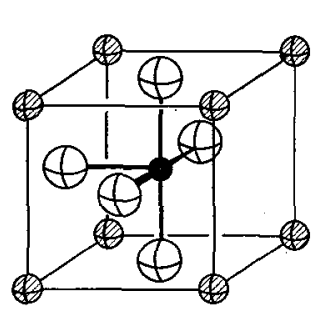

DIPOLAR LIGAND VACANCY $\mathrm{SnCl}_{5} \square^{-}$

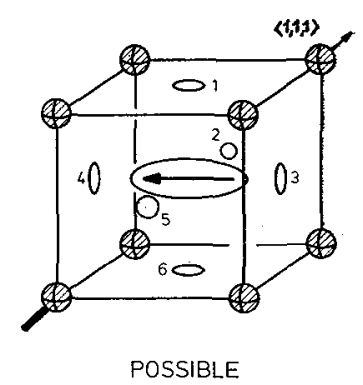

DIPOLE ORIENTATIONS
Frg. 1. - Primitive cell of the cubic structure of $\mathrm{K}_{2} \mathrm{SnCl}_{6}$ (upper part); dipolar pentacoordinated complex with ligand vacancy and its possible orientations in a cubic cell (lower part).

tionally incorporated for $\mathrm{NH}_{4}^{+}$on growing the crystals and stabilized by divalent cationic impurities [28].

Experimental. - $\mathrm{K}_{2} \mathrm{SnCl}_{6}$ raw material was synthesized by conventional methods [29] and purified by multiple recrystallisation from aqueous solution. Single crystals were grown from $0.1 \mathrm{n} \mathrm{HCl}$ solution. $\mathrm{NH}_{4} \mathrm{Cl}$ and $\mathrm{NH}_{4} \mathrm{Br}$ single crystals were grown in the Institut für Kristallographie der Universität zu Köln (Prof. $\mathrm{S}$. Haussühl) from aqueous solution of commercial high purity raw material with urea added as a habit modifier.

Slices of about $(0.5 \times 8 \times 8 \mathrm{~mm})$ typical size were cut parallel to the natural crystal faces, i. e. $(1,1,1)$ in the case of $\mathrm{K}_{2} \mathrm{SnCl}_{6}$ and $(1,0,0)$ in the case of $\mathrm{NH}_{4} \mathrm{Br}$ and $\mathrm{NH}_{4} \mathrm{Cl}$. The plates were etched with $0.1 \mathrm{n}$ $\mathrm{HCl}$ and $\mathrm{H}_{2} \mathrm{O}$, respectively, polished and supplied with colloidal graphite contacts.

Thermal neutron irradiations were performed at about $300 \mathrm{~K}$ in the thermal column BE-14 of the FRJ-1 (Merlin), a position with negligible flux of fast neutrons and $\gamma$-rays. Typical doses applied were $D_{n+\mathrm{b}}=4-5 \times 10^{15} \mathrm{~cm}^{-2}$, leading to a concentration of $1.4 \times 10^{-6}$ ligand vacancies per molecule [3-5], i. e. about $4 \times 10^{14}$ ligand defects in the sensitive region between the contacts.

D. C. conductivity and ITC measurements were performed in a vacuum cryostat connected to a Keithly-640 vibrating capacitor electrometer, cf. figure 2. The system was designed similar to that by Dr. Kokott, Institut für Festkörperphysik, Universität Münster. It consists of a cylindrical vessel, the

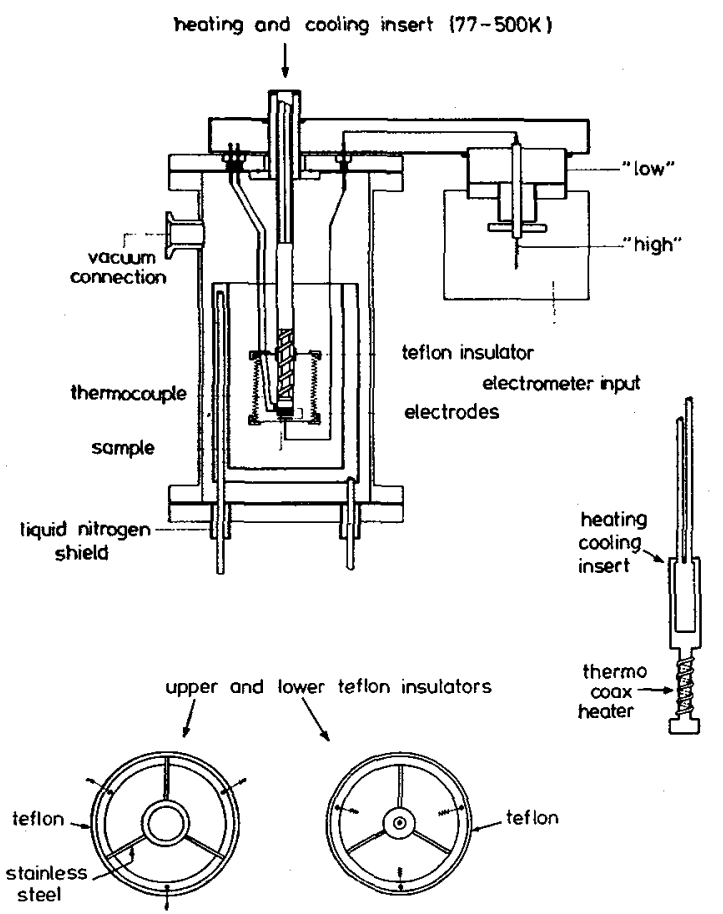

Fig. 2. - Cryostat system for dielectric measurements.

cover of which carries the sample holder. This $300 \mathrm{~mm}$ long stainless steel tube is closed at the lower end and serves as the low electrode. The high electrode is a very thin stainless steel plate which is pressed gently against the end of the tube by means of a spring system, figure 2. A thermocouple is welded at the end of the tube. The electric resistance of the whole system is higher than $5 \times 10^{15} \Omega$; the lowest resolvable current is about $1 \times 10^{-15} \mathrm{~A}$. A liquid nitrogen cold trap within the cryostat prevents the condensation of residual gas on the sample. Heating and cooling over a temperature range from 77 to $500 \mathrm{~K}$ is achieved by a device insertable into the low electrode tube, cf. figure 2. A constant heating rate of $3.2 \mathrm{~K} \mathrm{min.}{ }^{-1}$ is obtained by pumping liquid nitrogen through the hollow copper block of the device and programmed electric counter heating.

D. C. conductivity measurements were performed after cooling the short-circuited crystals to $77 \mathrm{~K}$, applying a D. C. field of $5 \mathrm{~V}$ and heating up to $500 \mathrm{~K}$. For ITC measurements the samples were polarized with $500 \mathrm{~V}$ for $5 \mathrm{~min}$ at room temperature, cooled to $77 \mathrm{~K}$ and short-circuited for $5 \mathrm{~min}$ before heating.

Results and discussion. - $\mathrm{K}_{2} \mathrm{SnCl} \mathrm{l}_{6}$. - The ITC spectra of non irradiated (dashed line) and neutron irradiated (solid line) $\mathrm{K}_{2} \mathrm{SnCl}_{6}$ in the temperature region near the phase transformations are shown in figure 3. As a consequence of the irradiation, sharp and intense depolarisation current peaks at $T_{1}$ and $T_{2}$ are observed, whereas in the non-irradiated sample only tiny humps can be seen. By annealing at temperatures above $350 \mathrm{~K}$ the intensity of the irradiation induced maxima and minima can be reduced. The 


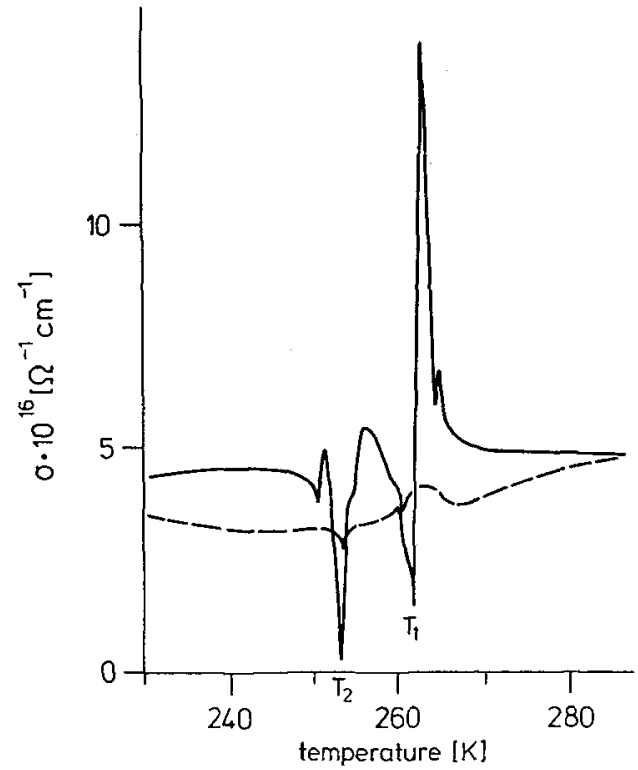

FIG. 3. - ITC spectra of $\mathrm{K}_{2} \mathrm{SnCl}_{6}$ in the region of the phase transitions (dashed line $=$ non irradiated sample, solid line $=$ irradiated with thermal neutrons; $T_{\mathrm{p}}=296 \mathrm{~K}$ ).

intensity of both peaks is found to decrease monotonically with decreasing polarization temperature down to $T_{2}$. Below this temperature the intensities remain constant.

The results of the irradiation experiments lead to the conclusion, that the current peaks at $T_{1}$ and $T_{2}$ cannot be produced by a classical spontaneous polarization of the crystals below the transition points, as it is observed e. g. for $\mathrm{NaNO}_{2}$ [31]. Also the observed tetragonal expansion at $T_{1}[13]$ is by far too small to explain the occurrence of the peaks via simple capacitance change. At $T_{2}$ a lattice parameter change was not found at all [13]. Thus, the anomalies at $T_{1}$ and $T_{2}$ are attributed to the stimulated rotation of $\mathrm{SnCl}_{5} \square^{-}$dipoles.

Figure 4 shows a schematic representation of an ITC experiment, involving the $T_{1}$-transition only.

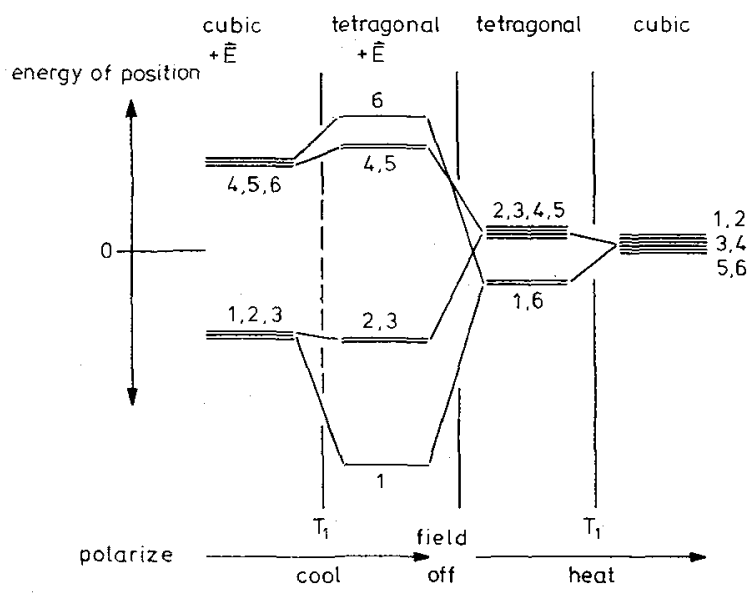

FIG. 4. - Schematic energy level scheme for orientation of dipolar units with ligand vacancies in an ITC experiment in $\mathrm{K}_{2} \mathrm{SnCl}_{6}$.
The orientation of the ligand vacancy is described in terms of energy levels (numbers refer to Fig. 1). Polarization of the sample in $(1,1,1)$ - direction at room temperature leads to a population of the three least energetic orientations 1,2 and 3 . On cooling the sample below $T_{1}$ an additional splitting of the levels may occur due to a tetragonal lattice distortion [13]. Since rotation of the ligand vacancy seems to be inhibited at temperatures below the phase transition, the former polarization is frozen in. When $T_{1}$ is reached from below on heating, the large fluctuations and possible $90^{\circ}$ jumps of the regular octahedra help the dipoles to occupy the six equivalent levels. This leads to a decrease of polarization and, thus, to the observed current anomalies. Domain effects, contributions from dilatation and not exact $(1,1,1)$ orientation of the samples may be responsible for the individual structure of the observed maxima and minima.

A similar explanation holds for the transition at $T_{2}$ as well. Because of the lower intensity of its peak, a small angle reorientation of the dipoles can be discussed, cf. [14].

The sensitivity of the method can be estimated from irradiation experiments with their typical concentration of $1.4 \times 10^{-6}$ ligand vacancies per molecule. Since the method allows the detection of intensities which are about 50 times smaller and an increase in polarization voltage by a factor of 3 to 5 is possible, a final resolution of some $10^{-9} \mathrm{SnCl}_{5} \square^{-}$-dipoles per molecule $\mathrm{K}_{2} \mathrm{SnCl}_{6}$ can be reached.

$\mathrm{NH}_{4} \mathrm{Cl}$ and $\mathrm{NH}_{4} \mathrm{Br}$. - The D. C. conductivity of $\mathrm{NH}_{4} \mathrm{Cl}$ and $\mathrm{NH}_{4} \mathrm{Br}$ in the temperature range from $100-500 \mathrm{~K}$ is shown in figures 5 and 6 , respectively, the region in vicinity of $T_{2}$ being additionally displayed in a linear scale as insertion. The consequences for the

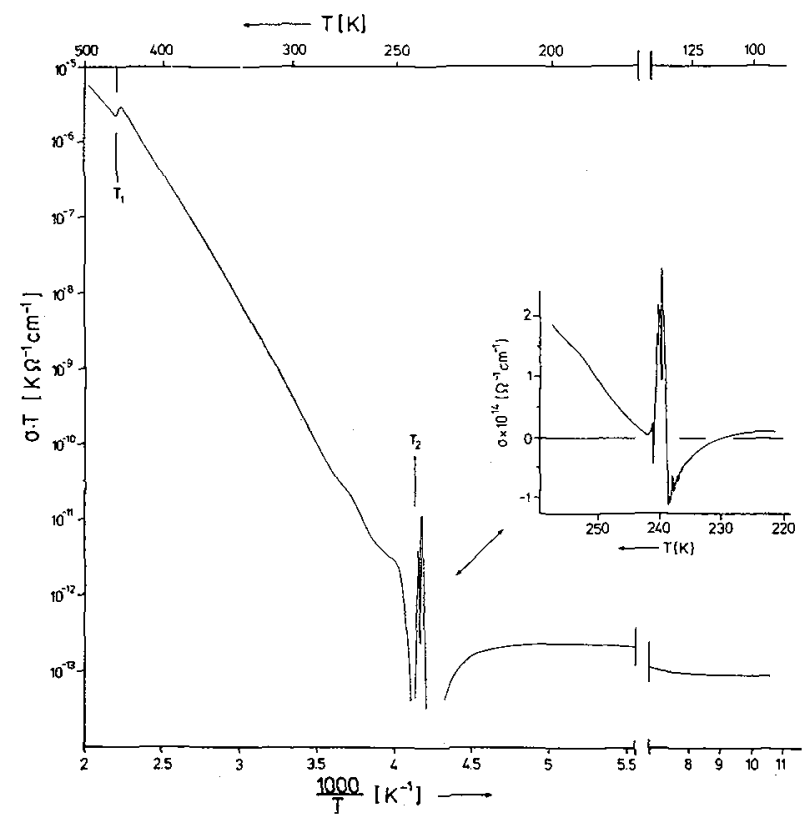

FIG. 5. - D. C. conductivity $(\sigma \cdot T)$ of $\mathrm{NH}_{4} \mathrm{Cl}$ (the region near $T_{2}=243 \mathrm{~K}$ is displayed in linear scale as insertion). 


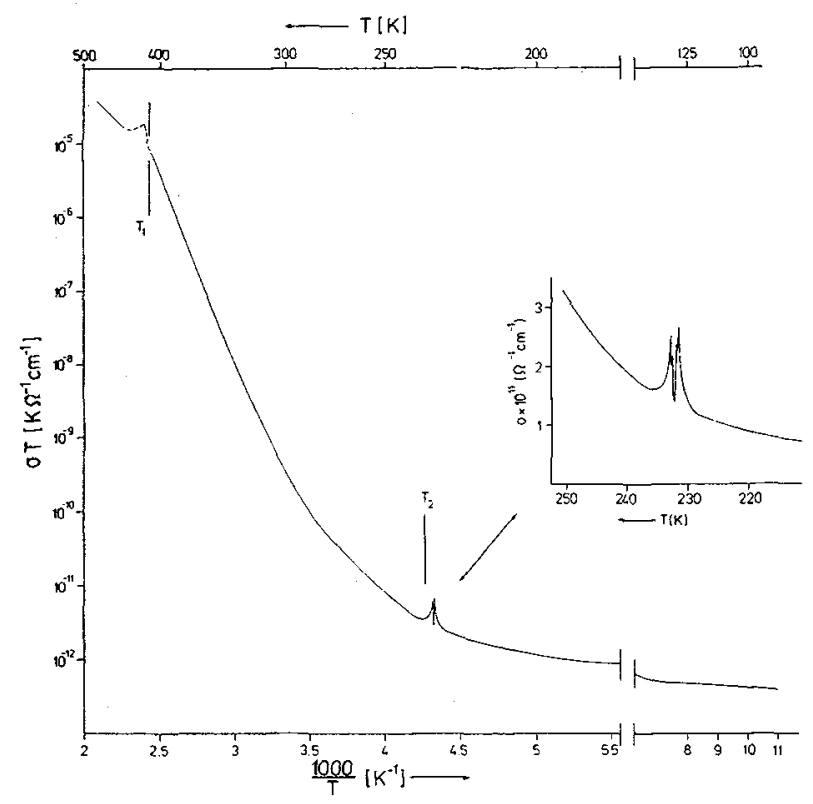

FrG. 6. - D. C. conductivity $(\sigma \cdot T)$ of $\mathrm{NH}_{4} \mathrm{Br}$ (the region near $T_{2}=243 \mathrm{~K}$ is displayed in linear scale as insertion).

conductivity behaviour of the high temperature transition $T_{1}$ have already been extensively treated by Murti and Prasad [27]. In the region of the low temperature transition $T_{2}$, sharp current peaks occur as in he case of $\mathrm{K}_{2} \mathrm{SnCl}_{6}$. The ITC spectra of $\mathrm{NH}_{4} \mathrm{Cl}$ and $\mathrm{NH}_{4} \mathrm{Br}$ are displayed in figure 7. They are very

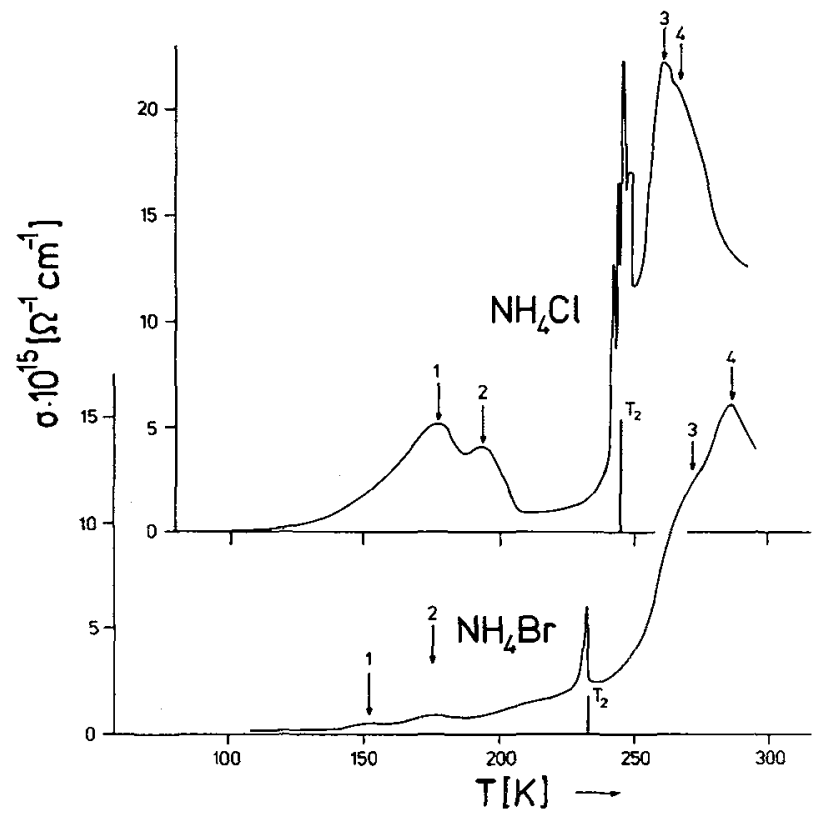

FIG. 7. - ITC spectra of $\mathrm{NH}_{4} \mathrm{Cl}$ (upper part) and $\mathrm{NH}_{4} \mathrm{Br}$ (lower part) $; T_{\mathrm{p}}=296 \mathrm{~K}$.

similar both showing sharp peaks at $T_{2}$ and ordinary dipole relaxation or space charge release bands (indexed 1, 2 and 3,4). A small temperature shift of the observed anomalies of about $2 \mathrm{~K}$ as compared to literature values of $T_{2}$ can be attributed to the rather high heating rate during the measurements. In figure 8 the ITC peak intensity for $\mathrm{NH}_{4} \mathrm{Br}$ at $T_{2}$ is plotted in a logarithmic scale versus the reciprocal polarization temperature $1 / T_{\mathrm{p}}$. An Arrhenius treatment leads to an formal activation energy of $(0.07 \pm 0.02) \mathrm{eV}$. No discontinuity is observed for $T_{\mathrm{p}}=T_{2}$.

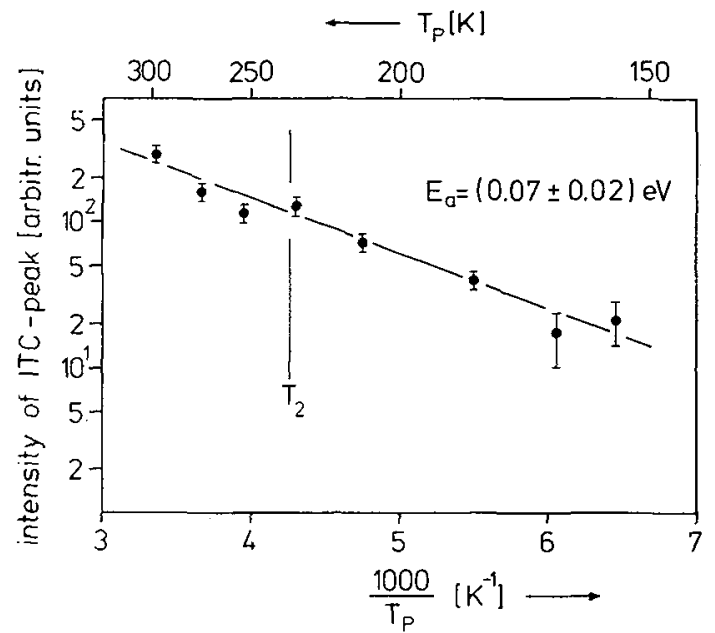

FIG. 8. - Intensity of ITC phase transition peak at $T_{2}=235 \mathrm{~K}$ in $\mathrm{NH}_{4} \mathrm{Br}$ as function of reciprocal polarization temperature.

Without previous polarization of the $\mathrm{NH}_{4} \mathrm{Br}$ crystal no peak could be found at $T_{2}$ within experimental resolution. Thus, a classical spontaneous polarization of the crystal below $T_{2}$ cannot be responsible for the peaks. Likewise, lattice dilatations are too small to account for the anomalies. In their ITC experiments in $\mathrm{NH}_{4} \mathrm{Cl}$, Kessler et al. $[28,32]$ also observed the maximum at $T_{2}$, the intensity of which increased with the concentration of $\mathrm{Ni}^{2+}$-impurities. In this case, a spontaneous polarization [32] of the defect arrangement cannot generally be excluded by our experiments. The difference in the nature of the phase transitions in $\mathrm{NH}_{4} \mathrm{Cl}$ (ferrodistortive, but no structural change) and $\mathrm{NH}_{4} \mathrm{Br}$ (antiferrodistortive and tetragonal distortion) may impede conclusions from one system to the other. Nevertheless, in view of the experiments under polarizing voltage, it seems to be reasonable to discuss the current anomalies in terms of dipolar relaxation of $\mathrm{NH}_{3}$-centers stabilized by divalent impurities. An analysis of the impurities of the ammonium halides via emission spectroscopy showed concentrations of divalent cations in the range of about 50 to 100 ppm.

Figure 9 (upper part) shows a $\mathrm{NH}_{3}$ dipole with its free electron orbital pointing into the fourth tetrahedral direction. In the vicinity of divalent cationic impurities, the free orbital of $\mathrm{NH}_{3}$ is directed towards the impurity, as could be shown by EPRexperiments [33, 34]. A rotation about the threefold symmetry axis is possible even at low temperatures, but it does not change the orientation of $\mathrm{NH}_{3}$. These motions are also dominant for the $\mathrm{NH}_{4}^{+}$-tetrahedra below $T_{2}$. At the transition point, however, the pro- 
bability for a rotation about the fourfold symmetry axis increases abruptly. By coupling to this new type of movement, the orientation of the $\mathrm{NH}_{3}$ dipole might be changed.
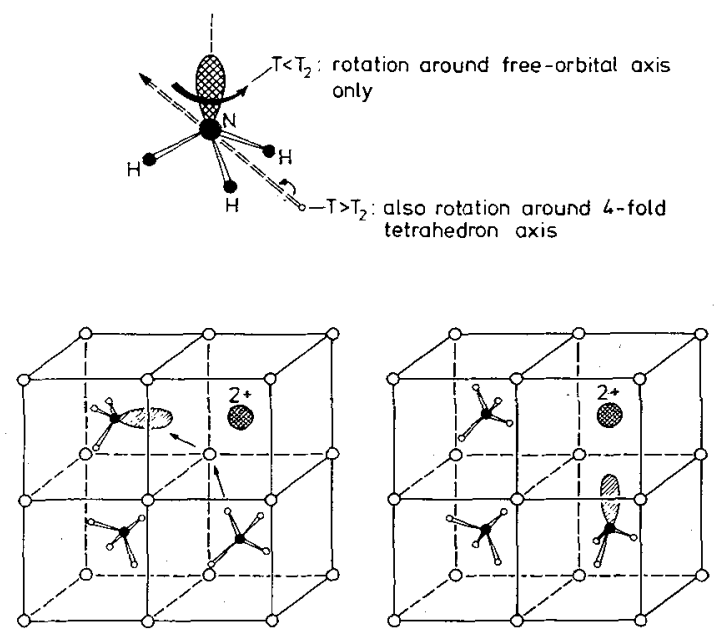

FrG. 9. - The two possible rotational modes for $\mathrm{NH}_{3}$-dipoles (upper part) ; orientation of $\mathrm{NH}_{3}$-dipole and motion by proton transfer in the vicinity of a divalent substitutional cationic impurity (lower part).

There is a second process, which may lead to a new static orientation of the dipole, the proton transfer from a neighbouring $\mathrm{NH}_{4}^{+}$to $\mathrm{NH}_{3}$, cf. figure 9 (lower part). Thus, the dipole moment is transferred to another molecule and its orientation stabilized again.

The mechanism of proton transfer can also account for the low activation energy and the constant slope of the ITC peak intensity at $T_{2}$ as function of reci- procal polarization temperature, cf. figure 8 . The intensity seems to be determined by the equilibrium concentration of oriented $\mathrm{NH}_{3}$-dipoles and, thus, by the enthalpy for proton transfer. The small activation energy for $\mathrm{NH}_{4} \mathrm{Br}$ agrees very well with that of $0.08 \mathrm{eV}$ reported by Murti and Prasad [26] for the proton jump in deformed $\mathrm{NH}_{4} \mathrm{Cl}$.

Conclusion. - The technique of stimulated dipolar relaxation may be successfully applied to a variety of insulators. The high sensitivity of the method allows the determination of low concentrations of defects, provided they have a permanent dipole moment and are triggered by lattice dynamics to change their orientation at phase transitions in a very short time interval. The technique is also selective for certain defect types, since sufficiently strong coupling of motions will only take place, if the defect structure is similar to that of the undamaged units. Alternatively, this method can also be used for a study of dynamical properties of the crystals at phase transformations. Due to the high sensitivity, only a small number of dipolar indicators is needed. This has the advantage of negligable disturbance of the lattice. In many cases a mild thermal neutron irradiation may provide the probes required.

Acknowledgment. - The authors are indebted to Prof. G. Stöcklin for his interest in the work and critical comments, and to Prof. S. Haussühl for the supply of single crystals of $\mathrm{K}_{2} \mathrm{SnCl}_{6}, \mathrm{NH}_{4} \mathrm{Cl}$ and $\mathrm{NH}_{4} \mathrm{Br}$. They gratefully acknowledge helpful discussion and experimental assistance of Prof. F. Fischer, Dr. Ch. Kokott, Dr. A. Kessler and Mr. M. Casey.

\section{References}

[1] Brill, T. B., Gearhart, R. C. and Welsh, W. A., J. Magn. Reson. 13(1974) 27.

[2] Bell, R., Rössler, K., Stöcklin, G. and Upabhyay, S. R., Rep. Jül-625-RC (1969) and J. Inorg. Nucl. Chem. 34 (1972) 461.

[3] Rössler, K., Otterbach, J. and Stöcklin, G., J. Phys. Chem. 76 (1972) 2499.

[4] Robinson, M. T., Rössler, K. and Torrens, I. M., $J$. Chem Phys. 60 (1974) 680.

[5] Rössler, K. and Robinson, M. T., in « Atomic Collisions in Solids », ed. Datz, S., Appleton, B. P. and Moak, C. D. (Plenum Publ. Corp., New York) 1975, Vol. I, p. 237.

[6] Edstrand, M., Inge, M. and Ingri, W., Acta Chem. Scand. 9 (1955) 122.

[7] Rössler, K. and WInTer, J., Chem. Phys. Lett. in press.

[8] Armstrong, R. L. and van Driel, H. M., Advances in $N Q R$-Spectroscopy, ed. Smith, J, A. S. (Heyden, London) Vol. II, 1975, p. 179.

[9] Morfee, R. G. S., Staveley, L. A. K., Walters, S. T. and Wigley, D. L., J. Phys. \& Chem. Solids 13 (1960) 132.

[10] Sasane, A., Nakamura, D. and Kubo, M., J. Magn. Reson. 3 (1970) 76.

[11] O'Leary, G. P. and Wheeler, R. G., Phys. Rev. B 1 (1970) 4409.

[12] JEFrREY, K. R., J. Magn. Reson. 7 (1972) 184.

[13] Boysen, H., Ihringer, J., Prandl, W. and Yelon, W., Solid State Commun. 20 (1976) 1019.
[14] Winter, J. and Rössler, K., AED-CONF-1975-056-105 ; Winter, J., Rössler, K. and Pelzl, J., AED-CONF1976-109-001.

[15] Winter, J., Rössler, K., Bolz, J. and Pelzl, J., Phys. Status Solidi (b) 74 (1976) 193.

[16] Bucci, C., Fieschi, R. and Guidi, G., Phys. Rev. 148 (1966) 816.

[17] Levy, H. A. and Peterson, S. W., Phys. Rev. 83 (1951) $1270 ; 86(1952) 766$.

[18] Bonilla, A., Garland, C. W. and Schumaker, N. E., Acta Crystallogr. A 26 (1970) 156.

[19] Fredericks, G. E., Phys. Rev. B 4 (1971) 911.

[20] Hüller, A., Z. Phys. 254 (1972) 456 ; 270 (1974) 343.

[21] Yelon, W. B., Cox, D. E. and Kortmann, P. J., Phys. Rev. B 9 (1974) 4843.

[22] Press, W., Eckert, J., Cox, D. E., Rotter, C. and Kamitakahara, W., Phys. Rev. B 14 (1976) 1983.

[23] Herrington, T. M. and Staveley, L. A. K., J. Phys. \& Chem. Solids 25 (1964) 921.

[24] Kröger, A. F., J. Chem. Phys. 51 (1969) 4025.

[25] Fuller, R. G. and Patten, F. W., J. Phys. \& Chem. Solids 31 (1970) 1539.

[26] Murti, Y. V. G. S. and Prasad, P. S., Solid State Commun. 15 (1974) 1619.

[27] Murti, Y. V. G. S. and Prasad, P. S., Physica 79B (1975) 243. 
[28] Berteit, P., Kessler, A. and List, T., Z. Phys. B 24 (1976) 15.

[29] BRAUER, G., Handbuch der präparativen anorganischen Chemie (F. Enke Verlag, Stuttgart), Vol. I, 1960, p. 649.

[30] WiNTER, J. and RössLER, K., AED-CONF-1975-204-020.

[31] Hamano, K., J. Phys. Soc. Japan 35 (1973) 157.
[32] Kessler, A., Proc. Symp. on Thermal and Photostimulated Currents in Insulators, ed. Smyth, M. (Dallas) 1975, p. 45.

[33] BoetTcher, F. and SPaeth, J. M., Phys. Status Solidi (b) 61 (1974) 465 ; (b) 62 (1974) 65.

[34] Kuroda, N. and Kawamori, A., J. Phys. \& Chem. Solids $32(1971) 1233$.

\section{DISCUSSION}

F. BÉNIÈRE. - What is the advantage of this method over the classical methods of determinations of phase transitions?

J. WINTER. - This method allows the determination of dynamic properties of phase transitions via the response of dipolar indicators. Thus, non-equilibrium effects may also be measured. In most of the classical studies the experiments are performed at fixed temperatures.

A. KessLer. - You mentioned, that you did not get any spontaneous signal (signal without polarization) in $\mathrm{NH}_{4} \mathrm{Br}$. That is to be expected in principle, because the defect arrangement is of the antiferrodistortive one in this case, whereas it is of the ferro. type in $\mathrm{NH}_{4} \mathrm{Cl}$.

J. WINTER. - Weak signals in $\mathrm{NH}_{4} \mathrm{Br}$ can arise from the fact that there are domains in the crystal.
A. L. LASKAR. - It is interesting to observe that the ITC method is so sensitive that a small depolarizing current during phase transition (order-disorder) in $\mathrm{NH}_{4} \mathrm{Cl}$ and $\mathrm{NH}_{4} \mathrm{Br}$ crystals can be monitored. We have also recently seen the ITC peak without applied electric field in $\mathrm{NH}_{4} \mathrm{Cl}$. I would like to know whether the phase transition at high temperature in $\mathrm{NH}_{4}$ halides can be monitored by this method.

J. WINTER. - The high temperature transitions in $\mathrm{NH}_{4} \mathrm{Cl}\left(T_{1}=457 \mathrm{~K}\right)$ and $\mathrm{NH}_{4} \mathrm{Br}\left(T_{1}=411 \mathrm{~K}\right)$ have been observed by DC-conductivity, cf. Figs 5 and 6 . Our results confirm those of Murti and Prasad, cf. ref. [27]. ITC-experiments should show a similar effect in principle. Observation and interpretation, however, may be impeded because of the fairly high conductivity of the substances at these temperatures and the frequent occurrence of large space charge bands. 